\title{
Keanekaragaman dan Kelimpahan Gastropoda di Pantai Seger, Lombok Tengah
}

\section{Diversity and Abundance of Gastropods at Seger Beach, Central Lombok}

\author{
Janaria Resdica Parorrongan ${ }^{\mathbf{1}}$, Felicia Zahida ${ }^{1 *}$, Ignatius Pramana Yuda ${ }^{\mathbf{1}}$ \\ ${ }^{1}$ Program Studi Biologi, Fakultas Teknobiologi, Universitas Atma Jaya Yogyakarta, Yogyakarta \\ Email: felicia.zahida@uajy.ac.id *Penulis untuk korespondensi
}

\begin{abstract}
Indonesia is rich with mollusca species i.e. about 1.500 species Gastropoda species. Gastropods are attractive animals based on their shell colour, size, shape and their wide distribution around intertidal, freshwater, mangrove, river ecosystem, and sea zones. The purpose ofthis study was to identify Gastropoda's diversity and abundance in Seger Beach Central Lombok from February to April 2018. This study used square transect method with plot size about $1 \times 1$ meter, sampling location 500 meters length, 50 meters of furthest flux, distance between plot was 10 meter, distance between transect lines were 50 meter, so 50 plots were used. The study result was based on Shanon Wiener's formulation of diversity index at the amount of 2,96 . Neritia albicilla was the most abundant spesies from Neritidae family with highest density value at the amount of 28.14 individual $/ \mathrm{m}^{2}$ and Monetaria annulus was the most unabundant species with lowest absolute density amount of 0.006 individual $/ \mathrm{m}^{2}$. Euplica scripta was species with highest absolute frequency value amount of 0.61. Engina maura and Virroconus ebraeus were species with the lowest absolute frequency value at the amount of 0.006 .
\end{abstract}

Keywords: Gastropods, Lombok, Central Lombok, Molluses

\begin{abstract}
Abstrak
Spesies moluska di Indonesia begitu banyak, yaitu sebanyak 1.5000 jenis Gastropoda. Gastropoda merupakan hewan menarik dengan berbagai warna, ukuran dan bentuk cangkang, dan mempunyai distribusi luas yang dapat meliputi wilayah intertidal, air tawar, mangrove, ekosistem sungai, wilayah daratan dan pada wilayah laut dalam. Penelitian ini bertujuan mengetahui keanekaragaman dan kelimpahan Gastropoda pada Pantai Seger, Lombok Tengah. Waktu penelitian yaitu pada bulan Februari-April 2018. Penelitian dilakukan menggunakan metode transek kuadrat, plot 1x1 m, dengan lokasi sampling sepanjang $500 \mathrm{~m}$, surut terjauh 50 $\mathrm{m}$, jarak antarplot $10 \mathrm{~m}$, jarak antargaris transek $50 \mathrm{~m}$ sehingga dihasilkan sebanyak 50 plot. Hasil keanekaragaman yang didapatkan berdasarkan indeks Shanon Wiener yaitu 2,96. Kelimpahan dengan nilai Densitas Tertinggi yaitu pada Famili Neritidae spesies Nerita albicilla sebesar 28,14 individu/m². Hasil Da paling rendah yaitu pada spesies Monetaria annulus yaitu 0,0006 individu $/ \mathrm{m}^{2}$. Spesies yang mempunyai nilai Frekuensi Absolut (FA) tertinggi yaitu Euplica scripta dengan nilai sebesar 0,61. Spesies yang mempunyai FA terendah yaitu spesies Engina maura dan Virroconus ebraeus sebesar 0,006.
\end{abstract}

Kata Kunci: Gastropoda, Lombok, Lombok Tengah, Moluska

Diterima: 10 Mei 2018 , disetujui: 1 Juni 2018

\section{Pendahuluan}

Indonesia dikenal sebagai negara kepulauan yang mempunyai wilayah laut dan perairan sebesar $75 \%$. Indonesia memiliki kekayaan yang begitu besar untuk moluska (Huffard dkk., 2012). Menurut Strong dkk.
(2008), bahwa moluska mencapai 100.000 spesies yang tersebar hampir diseluruh dunia. Menurut Dharma (1988), sekitar 20\% jenis moluska di dunia tersebut hidup di Indonesia. Nontji (2002), juga menambahkan terdapat 1.500 jenis Gastropoda yang ada Indonesia. 
Menurut Nurdin dkk. (2009), Gastropoda secara umum telah dipanen dan dimanfaatkan untuk kebutuhan protein dan komersial. Cangkang kerang memiliki nilai ekonomis sebagai bahan perhiasan dan dagingnya digunakan dalam bidang budidaya udang sebagai suplemen protein. Zahida (2002), menambahkan bahwa maraknya suatu penjualan kerajinan berbahan cangkang dapat menimbulkan kekhawatiran mengenai eksploitasi komunitas Gastropoda.

Effendi dan Hadiprajitno (2013), menambahkan terdapat beberapa jenis keong yang diminati oleh kolektor cangkang yang mengkoleksi cangkang keong yang tersebar di seluruh dunia seperti keong yang berasal dari famili Diplommatinidae, pada umumnya keong ini mempunyai bentuk cangkang yang unik, sehingga dapat laku di pasaran kolektor cangkang dengan harga rata-rata yang ditawarkan sekitar 5-20 US\$ per cangkang.

Penelitian yang dilakukan oleh Marwoto (2016), tentang Keong Darat melaporkan bahwa eksploitasi juga terjadi pada Amphidromus bulowi yang berasal dari Sumatera Tengah dan merupakan keong endemik yang langka. Menurut Effendi dan Hadiprajitno (2013), keong ini mempunyai cangkang yang laku di pasaran kolektor dunia dengan harga 1000 Euro. Ada pula spesies yang dijadikan bahan makanan yaitu moluska dari famili Cardiidae yang banyak dimakan oleh masyarakat Asia terutama Malaysia (Dholakia, 2013).

Contoh lain terjadi pada Gastropoda dari famili Cypraeidae yaitu spesies Monetaria annulus, Monetaria caputserpentis, Monetaria moneta, dan dari famili Buccinidae yaitu Engina mendicaria yang di eksploitasi secara besarbesaran untuk dijadikan bahan baku hiasan dengan kisaran harga mencapai\$1, 10 per cangkang (Kusnadi, 2017).

Pulau Lombok masuk dalam kawasan Wallacea sehingga pulau ini mempunyai keanekaragaman hayati yang tinggi, termasuk moluska (Burung Indonesia, 2014). Pulau Lombok salah satu tujuan utama wisatawan datang ke Indonesia dan Pantai Seger merupakan pantai wisata di daerah Lombok tengah sehingga banyak masyarakat yang berkunjung ke pantai ini. Hal ini menurut Zahida dan Jati (2015), dapat menjadi keuntungan sendiri bagi masyarakat sekitar dikarenakan adanya kenaikan pendapatan, namun dampak negatif dapat terjadi yaitu adanya masalah penanganan yang ekstra dan upaya-upaya konservasi bagi moluska.

Kajian mengenai keanekaragaman moluska khususnya Gastropoda di Pulau Lombok masih sangat terbatas, karena masyarakat Indonesia lebih tertarik untuk berlibur dibandingkan melakukan penelitian pada Pulau Lombok. Penelitian mengenai Gastropoda penting dilakukan juga pada Pantai Seger, Lombok Tengah dengan tujuan mengetahui keanekaragaman dan kelimpahan Gastropoda.

\section{Metode Penelitian}

\section{Lokasi dan Waktu Penelitian}

Lokasi Penelitian dilakukan pada Pantai Seger, Lombok Tengah (Gambar 1).Waktu penelitian dilaksanakan pada bulan FebruariApril 2018.

\section{Alat dan Bahan}

Alat-alat yang digunakan dalam penelitian ini yaitu kamera HP, penggaris, pipet ukur, propipet, syringe, wadah atau botol jam, meteran, buku catatan, bolpoin, GPS, transek, pinset, $\mathrm{pH}$ meter, refraktometer, senter, dan termometer batang. Bahan-bahan yang digunakan dalam penelitian ini adalah air laut, larutan $\mathrm{NaOH}$, larutan $\mathrm{MnSO}_{4}$, larutan $\mathrm{KOH}-\mathrm{KI}$, larutan $\mathrm{H}_{2} \mathrm{SO}_{4}$ pekat, indikator amilum, larutan $\mathrm{Na}_{2} \mathrm{~S}_{2} \mathrm{O}_{3}$, dan indikator phenolpthalein (PP).

\section{Penentuan Wilayah}

Penentuan wilayah sampling dilakukan dengan cara melakukan survei langsung ke Pantai Seger, Lombok Tengah.

\section{Pengambilan Sampel}

Pengambilan sampel berupa Gastropoda dilakukan dengan dua tahap, tahap pertama pada saat survei yang dilakukan pada 28 Agustus-6 September 2017 dengan metode jelajah dan tahap kedua pada saat penelitian berlangsung Februari-April 2018. 


\section{Dokumentasi dan Identifikasi Sampel}

Dokumentasi pada sampel Gastropoda dilakukan setelah pengambilan sampel dilokasi penelitian, lalu dilakukan diidentifikasi dengan menggunakan situs resmi yaitu http://Conchology.be.

\section{Peletakan Transek}

\section{Gambar 2}

Peletakan transek yang ditunjukkan pada

Penelitian ini menggunakan metode transek kuadrat (Gambar 2) yang didasarkan pada intensitas sampling (IS) yang menurut Peraturan Menteri Kehutanan Republik Indonesia No P.33. 2009. Intensitas Sampling
(IS) dapat dilakukan dengan menggunakan rumus sebagai berikut :

Intensitas Sampling (IS) =

Jumlah Luasan Plot yang digunakan

Jumlah Luasan Kajian

Intensitas Sampling (IS) =

$$
\frac{50 X 1 \mathrm{~m} X 1 \mathrm{~m}}{4000 \mathrm{~m} X 5 \mathrm{~m}} X 100 \%=0,025 \%
$$

Panjang lokasi Pantai Seger yaitu 4.696,23 meter, surut terjauh yaitu 50 meter, dengan Intensitas Sampling (IS) yang didapatkan yaitu $0,025 \%$ dengan jumlah plot yaitu 50 plot dan ukuran plot yang digunakan yaitu $1 \times 1 \mathrm{~m}$.

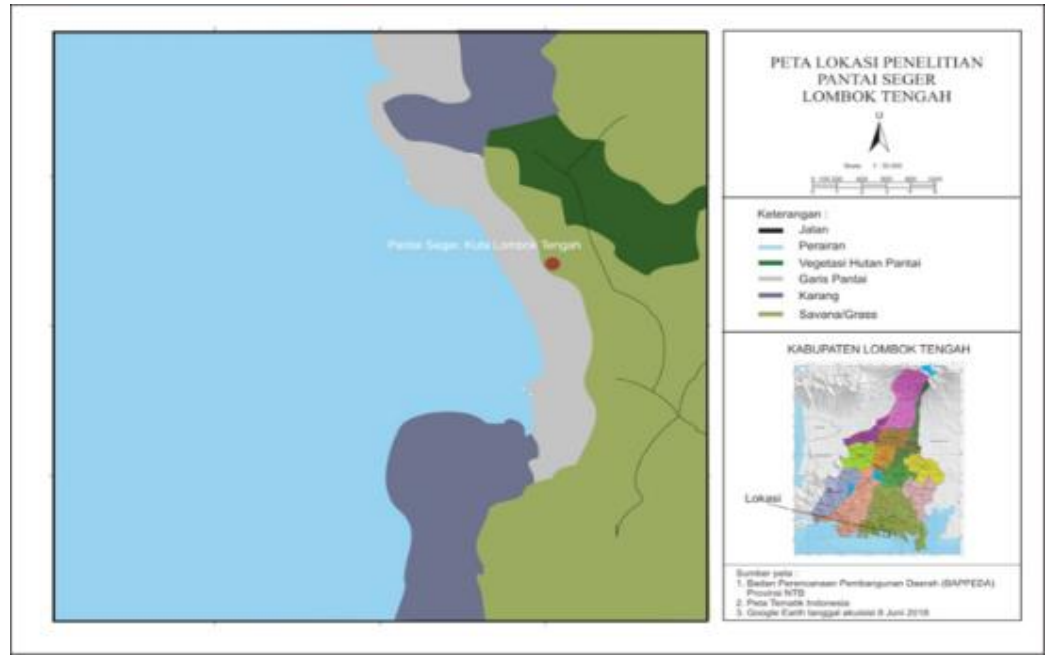

Gambar 1. Peta Wilayah Pantai Seger, Lombok Tengah.

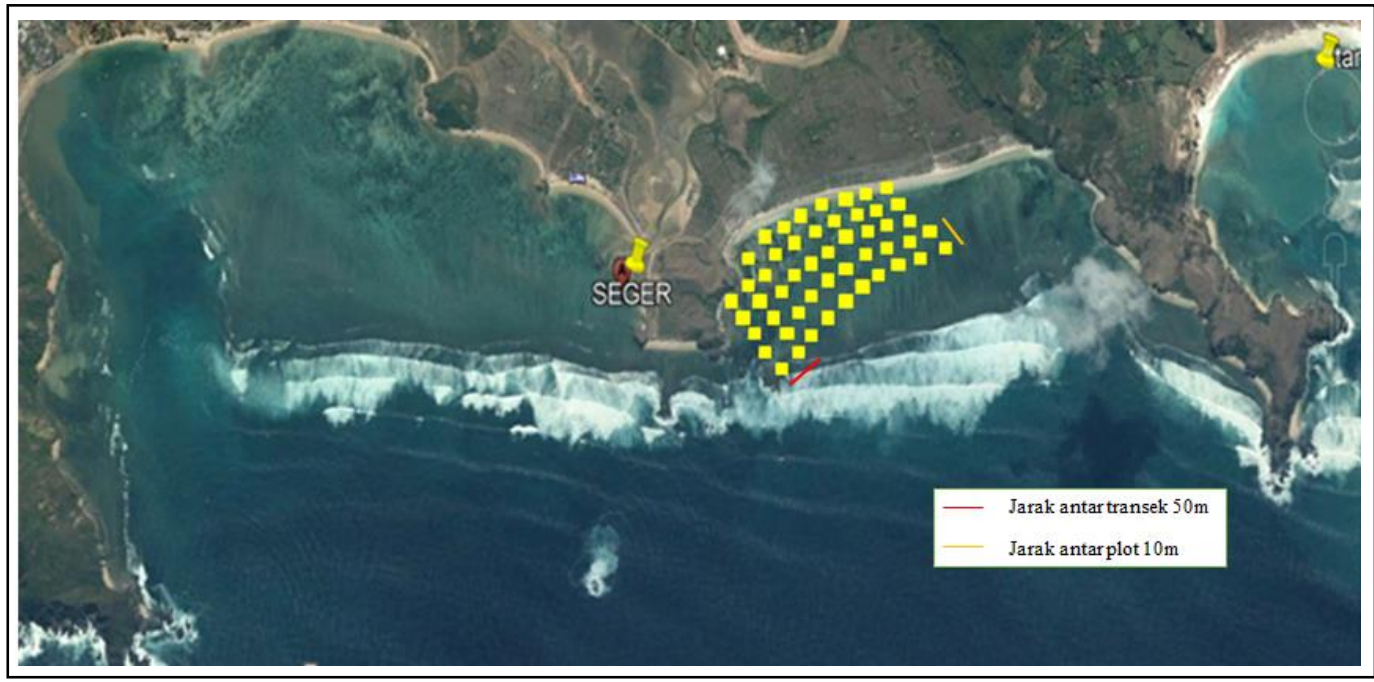

Gambar 2. Rancangan pemetaan peletakan garis transek di Pantai Seger, Lombok Tengah, dibuat dengan Google earth. 
Lokasi sampling 500 meter menggunakan jumlah garis transek sebanyak 10 buah garis transek, pada setiap garis transek terdapat 5 plot.Jarak per plot 10 meter dalam satu garis transek, dengan jarak per garis transek yaitu sepanjang 50meter, sehingga dihasilkan sebanyak 50 plot. Panjang garis transek yang digunakan berdasarkan pasang surut terjauh, yaitu sepanjang 50meter. Metode yang digunakan yaitu metode transek kuadrat dengan pengambilan data dilakukan sebanyak 3 kali pada bulan Februari sampai dengan bulan April 2018.

\section{Perhitungan Keanekaragaman dan Kelimpahan}

Kelimpahan dan Indeks Keanekaragaman, dapat dihitung dengan menggunakan rumus oleh Odum (1993).

\section{Kelimpahan populasi}

1. Densitas Absolut $=\frac{\text { Iumlah Individu }}{\text { jumlah plot }}$

2. Densitas Relatif $=\frac{\text { Kerapatan Spesies i }}{\text { Kerapatan Seluruh Spesies }}$

3. Frekuensi Absolut $=\frac{E \text { Plotyang terdapat pada spesies i }}{\text { Iumlah Total Plot }}$

4. Frekuensi Relatif $=\frac{\text { Frekuensi spesies i }}{\text { Frekuensi seluruh spesies }} \times 100 \%$

\section{Keanekaragaman Populasi}

Indeks keanekaragaman dapat dihitung dengan menggunakan metode Shanon-Wiener yaitu :

$\mathrm{H}^{\prime}=-\sum \mathrm{ni} / \mathrm{N}$ Ln ni / N atau $\mathrm{H}=$-pi Lnpi

\section{Faktor Lingkungan Fisika dan Kimia}

Pengukuran faktor lingkungan dilakukan 2 kali pada awal dan akhir sampling.Pengukuran yang dilakukan berupa pengukuran suhu, $\mathrm{pH}$, salinitas, $\mathrm{CO}_{2}$ dan DO. Pengukuran faktor lingkungan ini dilakukan pada transek (stasiun) 1, 5, dan 10 diharapkan dapat mewakili keseluruhan daerah kajian, hasil pengukuran yang didapatkan dirata-rata untuk mengetahui range batas hidup dari Gastropoda.

\section{Hasil dan Pembahasan}

\section{Kekayaan Jenis Gastropoda pada Pantai Seger, Lombok Tengah}

Berdasarkan penelitian yang telah dilakukan di Pantai Seger, Lombok Tengah hasil survei dengan metode jelajah didapatkan 28 spesies yang termasuk dalam 9 famili dan hasil pada bulan Februari-April 2018 dengan metode transek didapat hasil keanekaragaman yaitu 26 spesies yang termasuk dalam 9 famili (Tabel 1).

Hasil yang ada menandakan bahwa spesies-spesies tersebut mempunyai adaptasi yang baik pada setiap substrat dan pantai yang berbeda-beda, hal ini dapat disebabkan daerah atau habitat yang ditempati mempunyai kecukupan makanan seperti alga dan kompetisi yang lebih sedikit. Selain itu, juga dapat dikarenakan pola penyebaran dari spesiesspesies tersebut tergolong umum dan tersebar secara merata, contohnya seperti spesies dari Famili Mitridae dan Cypraeidae yang memiliki penyebaran secara umum di Indo Pasific (Abbott, 1970). Famili Conidae dan Buccinidae memiliki penyebaran pada laut tropis (Tinker, 1952).

\section{Indeks Keanekragaman Gastropoda}

Pantai Seger memiliki indeks keanekaragaman Gastropoda sebesar 2,96 \pm 0,39. Keanekaragaman Gastropoda Pantai Seger dapat dikatakan tinggi karena memiliki indeks keanekaragaman yang lebih tinggi daripada indeks keanekaragaman Gastropoda di beberapa pantai lain di Indonesia (Tabel 2).

Hasil ini dikarenakan pantai Seger merupakan pantai dengan substrat baik yaitu berbatu, pasir berlumpur dan terdapat hamparan lamun yang dapat mendukung pertumbuhan dan perkembangbiakan dari Gastropoda. Menurut Yuniarti (2012) keanekaragaman Gastropoda dipengaruhi oleh kesuburan habitat yang ditempati suatu spesies. Seperti banyaknya ketersediaan makanan dan sedikitnya persaingan.

Arbi (2011), menambahkan tinggi rendahnya suatu indeks keanekaragaman disebabkan karena berbagai faktor yaitu adanya jumlah jenis atau individu yang ditemukan dalam jumlah yang melimpah daripada jenis 
yang lainnya, kondisi substrat, kondisi tiga ekosistem (terumbu karang, mangrove dan padang lamun) di wilayah pesisir yang menjadi habitat utama dari hampir seluruh fauna perairan.

\section{Kelimpahan Gastropoda}

Spesies dengan nilai Densitas Absolut (DA) paling tinggi yaitu Nerita albicilla, dengan nilai Densitas Absolut sebesar 28,14 individu $/ \mathrm{m}^{2}$ (Tabel 3). Hasil DA paling rendah yaitu pada spesies Monetaria annulus 0,006 individu $/ \mathrm{m}^{2}$. Frekuensi dapat menunjukan suatu nilai penyebaran dari spesies.Spesies yang mempunyai nilai Frekuensi Absolut (FA) tertinggi yaitu Euplicascripta dengan nilai sebesar 0,61. Spesies yang mempunyai FA terendah yaitu Monetaria annulus, Engina maura dan Virroconus ebraeus sebesar 0,006.

Hasil densitas dan frekuensi yang tinggi dikarenakan spesies tersebut memiliki sebaran yang luas, yakni mempunyai tingkat kehadiran lebih merata pada daerah kajian sehingga lebih banyak ditemui, selain itu tingginya nilai densitas dan frekuensi dikarenakan Nerita albicilla dan Euplicascripta merupakan golongan herbivora, yang makanannya berupa alga atau seresah dari tumbuhan yang menempel pada substrat batuan pantai, banyaknya ketersediaan makanan yang mengakibatkan spesies dengan nilai tertinggi mampu beradaptasi dengan baik dengan tingkat kompetisi yang jarang atau tidak ada sama sekali.

Tabel 1.Keanekaragaman spesies Gastropoda di Pantai Seger, Lombok Tengah berdasarkan metode jelajah dan metode transek

\begin{tabular}{|c|c|c|c|c|}
\hline \multirow{2}{*}{ No. } & \multirow{2}{*}{ Famili } & \multirow{2}{*}{ Spesies } & \multicolumn{2}{|c|}{ Metode } \\
\hline & & & Jelajah & Transek \\
\hline \multirow[t]{6}{*}{$\overline{1 .}$} & Buccinidae & 1. Aferafer & $\sqrt{1 \sqrt{ }}$ & \\
\hline & & 2. Buccinulum linea linea & $\sqrt{ }$ & $\sqrt{ }$ \\
\hline & & 3. Engina fusiformis & $\sqrt{ }$ & $\sqrt{ }$ \\
\hline & & 4. & $\sqrt{ }$ & $\sqrt{ }$ \\
\hline & & maura & $\sqrt{ }$ & $\sqrt{ }$ \\
\hline & & 5. Engina mendicaria & & \\
\hline 2. & Cerithiidae & 1. Rhinoclavis sinensis & $\sqrt{ }$ & $\sqrt{ }$ \\
\hline \multirow[t]{3}{*}{3.} & Columbellidae & 1. Euplicascripta & $\sqrt{ }$ & \\
\hline & & 2. Pictocolumbella ocellata & $\sqrt{ }$ & $\sqrt{ }$ \\
\hline & & 3. Amphissa Versicolor & $\sqrt{ }$ & \\
\hline 4. & Conidae & 1. Virroconus ebraeus & $\sqrt{ }$ & $\sqrt{ }$ \\
\hline \multirow[t]{5}{*}{5.} & Cypraeidae & 1. Arestorides argus argus & $\sqrt{ }$ & $\sqrt{ }$ \\
\hline & & 2. Bistolida kieneri kieneri & $\sqrt{ }$ & $\sqrt{ }$ \\
\hline & & 3. Cypraea annulus $x$ poraria & $\sqrt{ }$ & $\sqrt{ }$ \\
\hline & & 4. Errona caurica caurica & $\sqrt{ }$ & $\sqrt{ }$ \\
\hline & & 5. Monetaria annulus DWARF & $\sqrt{ }$ & $\sqrt{ }$ \\
\hline \multirow[t]{3}{*}{6.} & Mitridae & 1. Morula granulate & $\sqrt{ }$ & $\sqrt{ }$ \\
\hline & & 2. Tiarella stictica & $\sqrt{ }$ & $\sqrt{ }$ \\
\hline & & 3. Strigatella pica & $\sqrt{ }$ & $\sqrt{ }$ \\
\hline \multirow[t]{5}{*}{7.} & Neritidae & 1. Nerita albicilla & $\sqrt{ }$ & $\sqrt{ }$ \\
\hline & & 2. Nerita costata & $\sqrt{ }$ & $\sqrt{ }$ \\
\hline & & 3. Nerita litterata & $\sqrt{ }$ & $\sqrt{ }$ \\
\hline & & 4. Clithon corona aff & $\sqrt{ }$ & $\sqrt{ }$ \\
\hline & & 5. Neripteron violaceum & $\sqrt{ }$ & $\sqrt{ }$ \\
\hline \multirow[t]{3}{*}{8.} & Turbinidae & 1. Pomaulax gibberosa & $\sqrt{ }$ & $\sqrt{ }$ \\
\hline & & 2. Turbo cidaris cidaris & $\sqrt{ }$ & $\sqrt{ }$ \\
\hline & & 3. Turbo argyrostomus argyrostomus & $\sqrt{ }$ & \\
\hline \multirow[t]{2}{*}{9.} & Volutidae & 1. Amoria zebra RUSTY & $\sqrt{ }$ & $\sqrt{ }$ \\
\hline & & 2. Cymbiola aulica & $\sqrt{ }$ & $\sqrt{ }$ \\
\hline
\end{tabular}


Tabel 2. Keanekaragaman Jenis Gastropoda di Beberapa Pantai di Indonesia

\begin{tabular}{lcc}
\hline \hline Lokasi Penelitian & H & Referensi \\
\hline \hline Teluk Mekaki, Lombok Barat & 2,16 & (Tunardi, 2018) \\
Wori Sulawesi Utara & 1,46 & (Arbi, 2011) \\
Teluk Tomini Gorontalo & 0,66 & (Sianu, 2014) \\
\hline \hline
\end{tabular}

Tabel 3. Hasil Nilai Densitas dan Frekuensi Gastropoda Pada Pantai Seger, Lombok Tengah.

\begin{tabular}{|c|c|c|c|c|c|}
\hline No & Spesies & DA & FA & DR & FR \\
\hline 1 & Afer afer & 0,02 & 0,02 & 0,0008 & 0,45 \\
\hline 2 & Amphissa versicolor & 0,82 & 0,09 & 0,12 & 4,62 \\
\hline 3 & Amoria zebra RUSTY & 0,06 & 0,02 & 0,009 & 0,99 \\
\hline 4 & Arestorides argus argus & 0,04 & 0,02 & 0,0001 & 1,36 \\
\hline 5 & Bistolida kieneri kieneri & 0,50 & 0,04 & 0,0002 & 3,14 \\
\hline 6 & Buccinulum linea linea & 0,02 & 0,02 & 0,0008 & 1,36 \\
\hline 7 & Clithon Corona aff & 0,16 & 0,06 & 0,011 & 1,44 \\
\hline 8 & Cymbiola aulica & 1,9 & 0,28 & 0,11 & 7,00 \\
\hline 9 & Cypraea annulus $x$ poraria & 1,44 & 0,51 & 0,07 & 34,56 \\
\hline 10 & Engina fusiformis & 0,13 & 0,09 & 0,007 & 6,21 \\
\hline 11 & Engina Maura & 0,01 & 0,006 & 0,0006 & 0,33 \\
\hline 12 & Engina mendicaria & 0,47 & 0,26 & 0,02 & 17,90 \\
\hline 13 & Errona caurica caurica & 0,11 & 0,02 & 0,005 & 0,99 \\
\hline 14 & Euplicascripta & 4,01 & 0,61 & 0,23 & 40,35 \\
\hline 15 & Monetaria annulus DWARF & 0,006 & 0,006 & 0,0003 & 0,99 \\
\hline 16 & Morula granulata & 0,02 & 0,02 & 0,0008 & 1,36 \\
\hline 17 & Nerita albicilla & 28,14 & 0,58 & 1,40 & 35,77 \\
\hline 18 & Nerita Costata & 1,96 & 0,32 & 0,11 & 22,50 \\
\hline 19 & Nerita litterata & 0,44 & 0,12 & 0,03 & 8,53 \\
\hline 20 & Neripteron violaceum & 0,02 & 0,02 & 0,001 & 0,99 \\
\hline 21 & Pictocolumbella ocellata & 0,07 & 0,02 & 0,003 & 0,99 \\
\hline 22 & Pomaulax gibberosa & 0,04 & 0,04 & 0,002 & 3,14 \\
\hline 23 & Rhinoclavis sinensis & 3,3 & 0,31 & 0,22 & 21,78 \\
\hline 24 & Turbo cidaris cidaris & 0,26 & 0,12 & 0,01 & 7,99 \\
\hline 25 & Turboargyrostomus argyrostomus & 0,01 & 0,006 & 0,0006 & 0,33 \\
\hline 26 & Virroconus ebraeus & 0,08 & 0,006 & 0,003 & 0,45 \\
\hline
\end{tabular}

Keterangan :

DA $=$ Densitas Absolut $\quad$ DR $=$ Densitas Relatif

$\mathrm{FA}=$ Frekuensi Absolut $\quad \mathrm{FR}=$ Frekuensi Relatif

Tabel 4. Pengukuran Parameter Lingkungan

\begin{tabular}{lcccc}
\hline \hline \multirow{2}{*}{ Parameter Lingkungan } & \multicolumn{4}{c}{ Hasil Pengukuran } \\
\cline { 2 - 5 } & Februari & Maret & April & Rerata \\
\hline \hline Suhu $\left({ }^{\circ} \mathrm{C}\right)$ & 27 & 29 & 28 & 28 \\
$\mathrm{pH}$ & 8,1 & 8,0 & 8,2 & 8,1 \\
Salinitas (\%o) & 32 & 33 & 31 & 32 \\
$\mathrm{CO}_{2}(\mathrm{ppm})$ & 0 & 0 & 0 & 0 \\
$\mathrm{DO}(\mathrm{mg} / \mathrm{L})$ & 5,3 & 4,9 & 5,4 & 5,2 \\
\hline \hline
\end{tabular}




\section{Kondisi Lingkungan di Pantai Seger, Lombok Tengah}

Hasil densitas dan frekuensi yang rendah memperlihatkan bahwa jenis Gastropoda ini memiliki kemampuan yang rendah dalam beradaptasi terhadap suatu habitat. Hal lain disebabkan karena spesies melakukan perpindahan tempat untuk mencari makanan, sehingga menyebabkan penyebarannya menjadi sedikit dan memiliki kehadiran yang jarang dalam daerah kajian. Monetaria annulus yang ditemukan memiliki nilai densitas dan frekuensi rendah, hal ini dikarenakan spesies dengan famili Cypraea merupakan spesies dengan mobilitas yang tinggi, yang artinya spesies ini akan berpindah tempat apabila daerah yang ditempati sebelumnya mulai kekurangan air (Zahida dan Jati, 2015). Hasil nilai densitas dan frekuensi rendah pada Monetaria annulus juga dapat disebabkan karena spesies ini mempunyai potensi menjadi bahan baku hiasan, sehingga telah terjadi eksploitasi terhadap spesies ini.

Hasil parameter lingkungan (Tabel 4) menunjukkan bahwa kualitas perairan di Pantai Seger, Lombok Tengah masih tergolong baik dan masih berada pada ambang batas baku mutu KEPMEN-LH No 51 Tahun 2004, sehingga masih dapat dikatakan layak untuk Gastropoda hidup dan berkembang biak. Berdasarkan data primer tahun 2016 yang dikutip dalam Putra Raka (2017)batas ambang baku mutu menurut KEPMEN-LH No 51 untuk suhu yaitu $28-30^{\circ} \mathrm{C}$ untuk pH yaitu 7-8,5, untuk salinitas yaitu 33$34 \%$ dan batas ambang baku mutu untuk DO yaitu $>5$

\section{Simpulan dan Saran}

\section{Simpulan}

Keanekaragaman Gastropoda yang didapatkan pada Pantai Seger, Lombok Tengah yaitu sebanyak 9 famili yang terdiri dari 26 spesies. Indeks Keanekaragaman yang didapatkan yaitu 2,96. Dan kelimpahan dengan nilai Densitas tertinggi yaitu Famili Neritidae spesies Nerita albicilla sebesar 28,14 individu $/ \mathrm{m}^{2}$. Hasil DA paling rendah yaitu pada spesies Monetaria annulus 0,0006 individu $/ \mathrm{m}^{2}$. Spesies yang mempunyai nilai Frekuensi
Absolut (FA) tertinggi yaitu Euplicascripta dengan nilai sebesar 0,61. Spesies yang mempunyai FA terendah yaitu spesies Engina maura dan Virroconus ebraeus sebesar 0,006.

\section{Saran}

Perlu adanya penelitian serupa terhadap Gastropoda di Pantai sekitar, dengan tujuan menambah data keragaman dan penyebaran Gastropoda di wilayah Lombok. Adanya Pengukuran Parameter Biologi terhadap Penelitian Sejenis..

\section{Daftar Pustaka}

Abbott, R.T. 1970. Indo Pacific Molusca Monographs Of The Marine Mollusks Of The World With Emphasis On Those Of The Tropical Western Pacific And Indian Oceans. Delaware Museum Of Natural History, Greenville, U.S.A.

Arbi, C.Y. 2011. Struktur Komunitas Moluska di Padang Lamun Perairan Pulau Talise, Sulawesi Utara. Oseanologi dan Limnologi di Indonesia, 37 (1) : $71-89$.

Burung Indonesia. 2014. Critical/Ecosystem Partnershio Fund. Ringkasan Ekosistem Wallacea. Hotspot Keragaman Hayati Wallacea. BirdLife International Pusat Kajian Sumberdaya Pesisir dan Lautan Institut Pertanian Bogor Samdhana Institute. Bogor.

Dharma. 1988. Siput dan Kerang Indonesia. PT Sarana Graha. Jakarta. Indonesia.

Dholakia, A.D. 2013. Identification of marine and freshwater: molluscs shells. New Delhi.

Effendi, S. dan dan Hadiprajitno, G. 2013. Rekor Tertinggi Spesimen Siput Darat Indonesia. Bertita Solaris, 16 (1): 3-1.

Huffard, C.L., Erdmann, M.V. dan Gunawan, T. 2012. Prioritas Geografi Keanekaragaman Hayati Laut Untuk Pengembangan Kawasan Konservasi Perairan diIndonesia. Kementerian Kelautan dan Perikanan (KKP) dan Marine Protected Areas Governance. Jakarta, Indonesia.

Marwoto, R.M. 2016. Keong Darat Dari Sumatera (Moluska, Gastropoda) the Occurence of the Terrestrial Snail From Sumatra (Mollusca, Gastropod). Zoo Indonesia, 25 (1): 8-21.

Nontji, A. 2002. Laut Nusantara. Djambatan, Jakarta.

Nurdin, J., Supriatna, J., Patria, M.P. dan A., dan B. 2009. The Potential Edible Bivalvia And Its Diversity In The Coastal Waters Of South Kabung Bay. Wes Sumatra: With Special Case Of Gafrarium 


\section{Keanekaragaman dan Kelimpahan Gastropoda}

Tomidum. Sumatera, Indonesia.

Odum, E.P. 1993. Dasar-Dasar Ekologi. Gajah Mada University Press, Yogyakarta.

Putra Raka, A. 2017. Keanekaragaman Gastropoda Berdasarkan Substrat Di Perairan Pantai Trikora. Fakultas Ilmu Kelautan dan Perikanan. Universitas Maritim Raja Ali Haji. Riau.

Sianu, E. 2014. Keanekaragaman dan Asosiasi Gastropoda dengan Ekosistem Lamun di Perairan Teluk Tomini. Ilmiah Perikanan dan Kelautan, 2: 2

Strong, E.E., Gargominy, O., Ponder, W.F., B.P. 2008 Global Diversity of Gastropods (Gastropoda; Mollusca) in Freshwater. hal.595:149-166.

Tinker, S.W. 1952. Pacific Sea Shells A Handbook of Common Marine Mollucs Hawaii and The
South Seas. Charles E. Turtle Company Publishers, Rytland, Vermont And Tokyo, Japan.

Yuniarti, Nur'aini. 2012. Keanekaragaman dan Distribusi Bivalvia dan Gastropoda (Moluska) di Pesisir Glayem Juntinyuat, Indramayu, Jawa Barat. Skripsi. Institut Pertanian Bogor: Bogor, Indonesia.

Zahida, F. 2002. Peran Gastropoda dan Bivalvia dalam Masyarakat Indonesia. Berita Solaris, 7 : 1 - 2 .

Zahida, F. dan Wibowo, N.Jati. 2015. Perkiraan Rentang Hidup dan Pola Osilasi Populasi Cypraea moneta L, 1758 Di Pantai Sepanjang Yogyakarta. Jurnal Perikanan, 17: 49-53. 